\title{
ASSESSMENT OF ECONOMIC POLICY VARIABLES THAT MODELED AGRICULTURAL INTENSIFICATION IN NIGERIA
}

\author{
Sunday B. Akpan \\ Department of Agricultural Economics and Extension, Akwa Ibom State University, Nigeria \\ Edet J. Udoh, Inimfon V. Patrick \\ Department of Agricultural Economics and Extension, University of Uyo, Nigeria
}

E-mail: brownsonakpan10@gmail.com

\begin{abstract}
Evidence has shown that, sustainable agricultural intensification amidst stable economic environment offers workable options to eradicate poverty and hunger. This study examined the trend in agricultural intensification and determined the influence of some macroeconomic variables from 1960 to 2014 in Nigeria. The result showed that, all series were integrated of order one. The exponential trend analysis of agricultural intensification revealed an average annual negative growth rate of $1.60 \%, 2.10 \%$ and $0.10 \%$ in Herfindahl, Ogive and Entropy intensification indexes respectively. The long-run and short-run elasticity of the agricultural intensification were determined using the techniques of co-integration and error correction models. The estimation of the error correction model supported the long run stability of agricultural intensification in Nigeria. The empirical results revealed that, in the long run; inflation, industrial output, external reserves, per capita income, and energy consumption were negative drivers of agricultural intensification; whereas crude oil prices, lending rate of Bank, foreign capital in agriculture and non-oil import works in opposite direction. However, in the short run, inflation, external reserves and industrial output retards agricultural intensification; while lending rate of Banks and crude oil price were stimulants. A ten-year out sampled forecast of agricultural intensification showed a steady declined. The empirical results were further substantiated by the variance decomposition and impulse response analyses. It is recommended that, the Nigeria government should re-aligned its macroeconomic policies to achieve stability in inflation rate, external reserves, industrial production, electricity consumption, agricultural credit institution to achieve sustainable agricultural intensification in the long run.
\end{abstract}

\section{KEY WORDS}

Agriculture development, macroeconomics, Sub-Saharan Africa, government, economy stabilization.

Agricultural sector has remained the center of most economic policies in Sub-Saharan countries. For instance in Nigeria, several phases of development policies have always focused on agricultural sector development. Following this interest, previous governments in the country have prioritized agricultural sector through enunciation and implementation of several intervention policies and programmes to regulate activities in the sector. During the early post-independence era, the source of intervention was mainly through the Development Plans and annual budgets (Lawal and Abe, 2011; Darma and Bappah (2014). These instruments were used by government to provide supportive funds to the sector in line with the import substitution policy framework of that era. Several agricultural related programmes and institutions were initiated and implemented to help intensify activities in the sector. For example: Agricultural Development Project (ADP); Agricultural based Research Institutions, Operation Feed the Nation (OFN); Agricultural Credit Guaranteed Scheme Fund (ACGSF), Green Revolution (GR); Strategic Grain Reserves (SGR), National Agricultural Land Development Authority (NALDA), Universities of Agriculture and National Economic Empowerment and Development Strategy (NEEDS) among others (Udoh \& Akpan, 2007; Ukoha, 2007; Akpan \& Udoh, 2009). Following the implementation of these policies and programmes in the country, the contribution of agricultural sector in the country's GDP stood at $48.79 \%$ in the period 1960 to 1969 and decelerated to $20.17 \%$ in the period 1970 to 1979 . 
The share increased to $31.53 \%$ in 1980 to 1989 and later declined to $26.03 \%$ in 1990 to 1999. However, it rose to $30.34 \%$ in 2000 to 2009 and $32.60 \%$ in the period 2010 to 2014 (CBN, 2014). Despite the recent increase in agricultural share in GDP, the country is still a net importer of grains and other agricultural commodities (CBN, 2014). About $63.8 \%$ of the rural population in the country lives below poverty line in 2004 (World Bank, 2014). The contribution of other non-oil sectors in the GDP revolved around a single unit growth rate for so many years, while youth unemployment mounted on yearly basis. The country depends heavily on crude oil exploitation. With increasing volatility in international crude oil price, sustainable economic development might not be attainable if sound economic policies are not implemented urgently. Policy pertaining to agricultural intensification seems to be one of the possible options available. This is stem from the fact that, about $37.3 \%$ of the country land mass is suitable for arable crop production with over $30 \%$ of the population constituting active labour force.

Agricultural intensification occurs when government, individual or organization increases resources to agricultural sector relative to other sectors of the economy. Alternatively, it occurs when the sector unceasingly dominant the share of its contribution to GDP relative to other non-oil sectors for a long period of time. Many proponents of agricultural intensification held that, intensification increase farmers outputs and hence, income and reduce rural poverty (Bernstein et al., 1992 and Rao et al., 2004). Report presented by World Bank (2007) showed that, growth in the agricultural sector reduced poverty three times faster than growth in any other sector like manufacturing, industry, or services. Hence, sustainable Agricultural Intensification offers workable options to eradicate poverty and hunger while improving the environmental performance of agriculture, but requires transformative, simultaneous interventions along the whole food chain, from production to consumption (International Food Policy Research Institute document, 2013).

Agricultural sector been part of the economy system is influenced by several macroeconomic variables (Sunday et al. 2012 and Olarinde and Hussainatu 2014). For instance, Ukoha, (1999) asserted that, agricultural sector performance in Nigeria shrinks due to distortions in exchange and interest rates. Similarly, Binswanger and Ruttan (1978) observed that, agricultural intensification in most Sub Saharan Africa is induced by government policies. By implication, the aggregate increase in resource allocation to agricultural sector is related to the stability of macroeconomic environment. The macroeconomic environment consists of the fiscal, monetary, exchange rate regimes and trade policies among other policies tended to regulate production activities in the real sectors and other sectors including the agricultural sector. Regrettably, macroeconomic policy outcomes in any economy vary greatly depending in part on the policy targets and instruments employed as well as operating environment (Agu, 2007). Sound macroeconomic policies are important to achieve national development targets through agricultural development (Fan et al., 2008). Macroeconomic variables have serious economic and development implication for the sustenance of agricultural production and stimulation of export.

Therefore, the country quest for sustainable agricultural intensification in the face of emerging liberal and competitive environment is vital to the long-term economic growth. Hence, understanding the relationship between the agricultural intensification and macroeconomic variables in the economy will fine-tune the path for sound policies on economic growth in the country. Such relationship is crucial and will be one of the reliable tools needed to accelerate productivity in the agricultural sector, sustained the environment as well as improved farmers' wellbeing in the country. Based on this premised, the paper was designed to investigate the level of agricultural intensification by using stream of incomes generated by the sector relative to other sectors in the economy. In addition, the study determined the relationship between agricultural intensification and some macroeconomic variables in the economy of Nigeria.

Reviewed of Related Literature. Several literature have explored the relationship between agricultural sector output and macroeconomic variables in Nigeria. For instance, Eyo (2008) established empirical linkages between macro- economic growth and agricultural 
productivity in Nigeria. His results revealed that nominal interest rate, and foreign private investment in agricultural have significant effects on the index of agricultural output in Nigeria. Omojimite (2012) investigated the impact of macroeconomic variables on agricultural growth using fully modified ordinary least squares approach. The results indicated that the volume of credit to the agricultural sector, deficit financing income and institutional reform were positively and significantly accounted for innovations in agricultural output for the period studied. In the same measure, Sunday et al (2012) studied the relationship between agricultural productivity and some key macroeconomic variables in Nigeria. The short-run and long-run elasticity of the agricultural productivity were determined using the techniques of co-integration and error correction models. The empirical results revealed that in the short and long run, the real total exports, per capita real income, external reserves, inflation rate and external debt have significant negative relationship with the agricultural productivity in the country; whereas industry's capacity utilization rate and nominal exchange rate exhibited positive relationship. Olarinde and Hussainatu (2014) studied the relationship between macroeconomic Policy and Agricultural Output in Nigeria. They used Vector Error Correction model and impulse response analysis. The result showed that in the long run, agricultural output was responsive to changes in government spending, agricultural credit, inflation rate, interest rate and exchange rate. The results further confirmed that government expenditure and interest rate reduce the agricultural output in the short, medium and long term. Furthermore, Akpan and Inimfon (2015) modeled palm oil, palm kernel and rubber annual output equations in Nigeria. The empirical results revealed that, per capita GDP, industrial capacity utilization, lending interest rate and kilowatts per capita of electricity influenced the output of palm oil, palm kernel and rubber in the long run; whereas, per capita GDP was significant variable in the short run.

Elsewhere, Gardener (1981) in US and Tangermann and Heihues (1973) in Europe have established empirical relationship between inflation and agricultural growth. Taimini et al. (2010) showed the significant of liberalisation policy on growth of beef export in Germany. Chisasa and Daniel (2015) found negative relationship between credit to agricultural sector and agricultural output growth in South Africa. Kwon and Koo (2009) asserted that exchange Rate and interest rate are the main macroeconomic shocks causing fluctuations in the agricultural sector."Msuya (2007) found positive relationship between foreign direct investment and agricultural output growth in Tanzania.

The reviewed literature measured activities in the agricultural sector by using agricultural output, agricultural production index and proportion of agricultural sector in the GDP. Some focused on the bilateral relationship between agricultural output/productivity and macroeconomic variables. Issues on agricultural intensification index is absent in the literature for Nigeria. The index is better than the aforementioned indexes because it take into consideration the contributions of other sectors in the economy. Also, it is bounded at the lower and upper limits. Bounds are important in order to classify the obtained index into perspective. Bounds make it clear whether a sector's income/activity is highly intensified or not. Hence, policy variables generated in this study will have direct bearing on agricultural intensification drive in Nigeria.

Measurement of Agricultural Concentration (Intensification) Index. There are several methods used to measure agricultural intensification in the literature. The study employed three methods to estimate index of agricultural intensification in the Nigeria's economy. One of the reasons was to compare calculated results in three different dimensions. The index was generated based on the structure of the Nigeria's GDP (Gross Domestic product at Current Basic Price). There are five major categories of income sources in the country GDP structure. These are Agricultural source; Industry source; Building and construction source, whole sale and retail trade source and service source. The summation of income from these five sources is equivalent to the annual GDP of Nigeria. Hence, agricultural intensification index was calculated based on the contribution of agricultural sector relative to other sectors in the total GDP of Nigeria. Hence, each measured of agricultural intensification is explained explicitly as thus: 
The Herfindahl Index. This index is estimated to measure agricultural intensification using agricultural sector's income in the GDP. The Herfindhal index $(\mathrm{HI})$ is a sum of the square of the proportion of agricultural income in the GDP. Since the GDP is an annual data, the Herfindhal index represents the summation of the proportion of agricultural share in the GDP within a year. It is described as follows:

$$
\mathrm{HCI}=\sum_{\mathrm{i}=1}^{\mathrm{N}} \mathrm{P}_{\mathrm{i}}^{2}
$$

where: $\mathrm{HCl}$ is Herfindhal intensification Index, $\mathrm{N}=$ total number of categorized income sources in the GDP and $\mathrm{P}_{\mathrm{i}}$ is the proportion of agricultural income $\left(\mathrm{Y}_{\mathrm{k}}\right)$ in the total income or $\operatorname{GDP}\left(\mathrm{Y}_{\mathrm{N}}\right)$. Hence, $\mathrm{P}_{\mathrm{i}}=\mathrm{Y}_{\mathrm{k}} / \mathrm{Y}_{\mathrm{N}}$. The value ranges from zero to one. It measures the degree of intensification of a particular income source in the total income, measured by the GDP of a given economy. Herfindhal concentration index of zero and unity imply complete diversification and intensification respectively of agricultural sector.

The Ogive index of Concentration. This index is also a measure of intensification. Following McLaughlin (1930) and Tress (1938), the Ogive index (OI) is constructed as follows:

$$
\text { OCI }=\sum_{\mathrm{i}=1}^{\mathrm{N}} \frac{\left\{\mathrm{P}_{\mathrm{i}}-\left(\frac{1}{\mathrm{~N}}\right)\right\}^{2}}{\left(\frac{1}{\mathrm{~N}}\right)}
$$

with $\mathrm{N}$ sources of income, equal sector's income distribution implies that $\mathrm{Pi}$ is equal to $1 / \mathrm{N}$. This represent an ideal share for each income source, and the Ogive index equals zero, meaning perfect diversity. A more unequal distribution of in the sectors income will result in a higher value of the Ogive index. It should, however, be noted that the measure is sensitive to the number of income sources aggregation (i.e., $\mathrm{N}$, the chosen number of income sources in the GDP) used to generate the intensification index. Following the work of Grossberg (1982) and Jackson (1984), a sector can be defined as being either diverse or specialized, relative to other sectors over time. Note variables are as defined previously in equation 1 and $\mathrm{OCl}$ is Ogive intensification index. When the $\mathrm{OCl}$ index approaches 0 , it means the agricultural sector is highly diversified; while a larger index indicates less diversification or more intensification.

The Entropy index. This index has a positive relationship with diversification and is inversely related to specialization. It approaches zero when the economy is fully specialized and takes a maximum value when there is perfect diversification. At perfect specialization, all income in the GDP is concentrated in just one category or sector such that Pi equal to unity. When this happens the Entropy will assume zero value. On the other hand, if income is distributed equally among the "N" sectors in the GDP, the Entropy index would reach its maximum value, indicating perfect diversity. In the case of " $N$ " sector, the range for the entropy index is zero to $\operatorname{Ln}(\mathrm{N})$. Hence, the upper limit of this Index depends on the base of logarithm and the number of income sources considered (Shiyani, 1998). Following Smith and Gibson (1988), the Entropy index of diversity can be defined as follows:

$$
E I=-\sum_{i=1}^{N} P_{i} \operatorname{In} P_{i} \text { or } \sum_{i=1}^{N} P_{i} \operatorname{In}\left(\frac{1}{P_{i}}\right)
$$

The index has the limitation of not giving standard scale when assessing the degree of diversification. The Entropy index defines diversity in terms of equality of distribution of income across all sources in the GDP. Hence, for ease of measuring intensification with this index, the calculated entropy index was subtracted from the upper bound (i.e. LnN), such that increase in the index is associated with increase in agricultural intensification. That is: $\mathrm{ECl}=\mathrm{Ln}(\mathrm{N})-\mathrm{El}$, where $\mathrm{ECl}$ is entropy intensification index. 


\section{RESEARCH METHODOLOGY}

Study Area: The study was conducted in Nigeria; the country is situated on the Gulf of Guinea in the sub Saharan Africa. Nigeria lies between $4^{0}$ and $14^{0}$ North of the Equator and between longitude $3^{0}$ and $15^{\circ}$ east of the Greenwich. The country has a total land area of about $923,769 \mathrm{~km}^{2}$ (or about 98.3 million hectares) with $853 \mathrm{~km}$ of coastline along the northern edge of the Gulf of Guinea and a population of over 140 million people (National Population Commission, 2006). The country is an agrarian society and depends so much on crude oil revenue. Currently, the country has the biggest economy in Africa.

Data source: Secondary data were used for the study. These data were sourced from the statistical bulletins of the Central Bank of Nigeria (CBN). Data were annual income from the five major component areas of the Nigeria GDP. The GDP computed at constant basic price was used in the study. Data covered the period from 1960 to 2014.

Analytical Techniques. The study applied descriptive, statistical and econometric techniques to analyze the specific objectives of the study. Explicitly they are explained as thus:

The trend Analysis of Agricultural intensification in Nigeria. The study investigated the nature of movement over time and growth rate in the estimated agricultural intensification indexes in Nigeria. An exponential trend equation was specified as thus:

$$
\log _{e} A C I_{t}=b_{0}+b_{1} T+U_{t}
$$

Where: ' $T$ ' is the time expressed in year; ACl's are estimated indexes of agricultural intensification in Nigeria. The exponential growth rate is given as:

$$
(r)=\left(e^{b 1}-1\right) * 100
$$

The Long run relationship between Agricultural Intensification Index and Macroeconomic variables in Nigeria. To determine the long run relationship between Agricultural intensification Index and selected macroeconomic variables in Nigeria, a time dependent regression model was specified at the level of variables. The model is specified as follows:

$$
\begin{aligned}
& \operatorname{LnACI}_{t}=\gamma_{0}+\gamma_{1} \sum_{i=1}^{n} \operatorname{LnCOP}_{t}+\gamma_{2} \sum_{i=1}^{n} \operatorname{LnPCG}_{t}+\gamma_{3} \sum_{i=1}^{n} \operatorname{LnINF}_{t}+\gamma_{4} \sum_{i=1}^{n} \operatorname{LnFDI}_{t} \\
& +\gamma_{5} \sum_{i=1}^{n} \operatorname{LnUEM}_{t}+\gamma_{6} \sum_{i=1}^{n} \operatorname{LnIEC}_{t}+\gamma_{7} \sum_{i=1}^{n} \operatorname{LnIMP}_{\mathrm{t}}+\mathrm{\gamma}_{8} \sum_{\mathrm{i}=1}^{\mathrm{n}} \text { LnLEN }_{\mathrm{t}} \\
& ++\mathrm{v}_{9} \sum_{\mathrm{i}=1}^{\mathrm{n}} \operatorname{LnCAS}_{\mathrm{t}}+\mathrm{v}_{10} \sum_{\mathrm{i}=1}^{\mathrm{n}} \operatorname{LnEXD}_{\mathrm{t}}+\mathrm{v}_{11} \sum_{\mathrm{i}=1}^{\mathrm{n}} \operatorname{LnEXR}_{\mathrm{t}}+\mathrm{v}_{12} \sum_{\mathrm{i}=1}^{\mathrm{n}} \operatorname{LnNOI}_{\mathrm{t}} \\
& +\mathrm{U}_{\mathrm{t}}
\end{aligned}
$$

Where;

$\mathrm{ACl}_{\mathrm{t}}=$ various measures of agricultural intensification Index $(\mathrm{HCl}, \mathrm{OCl}$ and $\mathrm{ECl})$

$\mathrm{COP}_{\mathrm{t}}=$ annual crude oil price per barrel $(\AA)$

$\mathrm{PCG}_{\mathrm{t}}=$ annual per capita GDP (A/Person)

$\mathrm{INF}_{\mathrm{t}}=$ annual Inflation rate $(\%)$

$\mathrm{FDI}_{\mathrm{t}}=$ foreign direct investment in Agricultural sector ( $\left.\mathrm{Am}\right)$

$\mathrm{UEM}_{\mathrm{t}}=$ annual unemployment rate in Nigeria (\%)

$\mathrm{IEC}_{\mathrm{t}}=$ index of energy consumption $(1985=100)(\%)$

$\mathrm{IMP}_{\mathrm{t}}=$ annual Index of manufacturing production $(1990=100)(\%)$

$\mathrm{LEN}_{\mathrm{t}}=$ average annual lending rate of commercial Bank (\%)

$\mathrm{CASt}=$ credit to agricultural sector/GDP 
$E X D_{t}=$ external debt/GDP

$\mathrm{EXR}_{\mathrm{t}}=$ external reserve/GDP

$\mathrm{NOI}_{\mathrm{t}}=$ value of non-oil import/GDP

$U_{\mathrm{t}}=$ Stochastic error term and $\mathrm{U}_{\mathrm{t}} \sim \operatorname{IID}\left(0, \delta^{2} \mathrm{u}\right)$.

To validate the existence of the long run stable relationship between the agricultural intensification index and some macroeconomic variables in Nigeria, the study applied the Engle and Granger two-step technique and Johansen co-integration tests. Following the Granger Representation Theorem, the Error Correction Model (ECM) for the co-integrating series in the study was specified. The general specification of the Error Correction Model for the agricultural intensification index equation in Nigeria is shown below:

$$
\Delta \operatorname{LnADI}_{\mathrm{t}}=\beta_{0}+\mathrm{v}_{1} \sum_{\mathrm{i}=1}^{\mathrm{n}} \Delta \mathrm{LnACI}_{\mathrm{t}-1}+\beta_{2} \sum_{\mathrm{i}=1}^{\mathrm{n}} \Delta \mathrm{LnX}_{\mathrm{t}-\mathrm{i}}+\beta_{3} \mathrm{ECM}_{\mathrm{t}-1}+\mathrm{U}_{\mathrm{t}} \ldots \text { (7) }
$$

The variables are as defined previously in equation 6 ; and coefficients $\left(\boldsymbol{\beta}_{3}\right)$ of the $\mathrm{ECM}_{\mathrm{t}}(-1<$ $\boldsymbol{\beta}_{3}<0$ ) measures the deviation from the long-run equilibrium in period $(\mathrm{t}-1)$.

Augmented Dickey-Fuller (ADF) - GLS Unit Root Test. Time series can be stationary or non-stationary at first or higher difference. Stationary series implies that, the series has constant mean, variance and minimal incidence of autocorrelation as well of time invariant (Brooks, 2008). On the other hand, a non-stationary series is time variant meaning it possess time varying mean, variance or both. The analysis of non- stationary series using the Ordinary Least Squares (OLS) estimation method will likely yield spurious or nonsense estimates (Gujarati, 2003). Hence, stationary of time series is needed to avoid the incidence of spurious regression. It is therefore necessary to convert non- stationary series to stationary status in order to obtain reliable regression estimates. In estimating an Error Correction Model, this study applies the Augmented Dickey- Fuller (ADF) - Generalized Least Squares (GLS) test to examine the stationary characteristics of specified series. As suggested by Dickey and Fuller (1981), equation (8) was used to test the stationary of specified variables.

$$
\Delta y_{t}=\mu_{t}+\alpha_{2} y_{t-1}+\sum_{i=1}^{k} \beta_{i} \Delta y_{t-i}+\varepsilon_{t}
$$

Where ' $y$ ' represents the variables to be tested, $\Delta$ represents the first difference operator; $t$ is the time drift; $\mathrm{k}$ represents the number of lags used and $\varepsilon$ is the error term, which is assumed to be normally and identically distributed with constant means and variance;' $\alpha$ and $\delta$ are the model bounds. It is a one-sided test whose null hypothesis is $\alpha_{2}=0$ versus the alternative $\alpha_{2}$ $<0$. Following the work of Elliott, Rothenberg and Stock (1996), ADF-GLS unit root involves estimating the standard ADF test equation after substituting the Generalized Least Squares detrended $y_{t}^{d}$ for the original $y_{t}$ as shown in equation (9). The test variant offers greater power than the regular ADF test.

$$
\Delta y_{t}^{d}=\alpha_{2} y_{t}^{d}+\sum_{i=1}^{k} \beta y_{t-1}^{d}+V_{t}
$$

\section{RESULTS AND DISCUSSION}

Descriptive Statistics. The descriptive statistics of variables used in the study is shown in Table 1. The result revealed an average value of about 0.156 for Herfindhal intensification index, 0.222 for $\mathrm{OCl}$ and 1.257 for entropy intensification index. The coefficient of variability of 0.017 (or about $1.7 \%$ variability) was obtained in entropy index. However, coefficient of variability in $\mathrm{HCl}$ was 0.608 and 1.151 in $\mathrm{OCl}$. This means that, about $60.80 \%$ and $115.10 \%$ 
variations occurred in $\mathrm{HCl}$ and $\mathrm{OCl}$ respectively within the period under consideration. The specified macroeconomic variables also showed varied degrees of variability and Skewness. For instance, average inflation rate of 16.104 was obtained from 1960 to 2014. Similarly, average crude oil price per barrel stood at $\$ 2611.31$, while the mean per capita GDP was A40894.3. Also, the mean inflation rate was about 16.104 among others. The degree of variability among specified macroeconomic variables was high indicating the dynamic nature of these variables. For instance, the crude oil price had coefficient of variability of 1.899 . This connotes that, about $189.90 \%$ of variation take place every year in crude oil price. This result shows the extent of time invariant in these specified series. This also suggests that, indexes of agricultural intensification and macroeconomic variables showed considerable variation in their distributions in Nigeria. Given this variation between these two set of variables, it is pertinent to establish their empirical relationship. The descriptive analysis was further enhanced by the trend analysis and graphical representation of estimated indexes of agricultural intensification in Nigeria.

Table 1 - Summary Statistics, using the observations from $1960-2014$

\begin{tabular}{lllllllll}
\hline Variable & Mean & Median & Min. & Max. & Std. Dev. & C.V. & Skewness & Ex. Kurtosis \\
\hline $\mathrm{HCl}$ & 0.156 & 0.117 & 0.041 & 0.403 & 0.0950 & 0.608 & 1.187 & 0.413 \\
$\mathrm{OCI}$ & 0.222 & 0.101 & 0.00002 & 0.945 & 0.256 & 1.151 & 1.513 & 1.141 \\
$\mathrm{ECI}$ & 1.257 & 1.246 & 1.242 & 1.321 & 0.021 & 0.017 & 1.531 & 1.430 \\
$\mathrm{COP}$ & 2611.31 & 64.56 & 0.864 & 17065.2 & 4959.9 & 1.899 & 1.940 & 2.495 \\
$\mathrm{PCG}$ & 40894.3 & 1164.43 & 48.517 & 242566 & 72208.5 & 1.766 & 1.765 & 1.747 \\
$\mathrm{INF}$ & 16.104 & 11.500 & 1.000 & 72.860 & 15.145 & 0.940 & 1.949 & 3.479 \\
$\mathrm{FDI}$ & 550.840 & 128.500 & 7.900 & 4060.63 & 726.332 & 1.318 & 2.214 & 7.710 \\
$\mathrm{UEM}$ & 8.028 & 5.100 & 1.900 & 27.300 & 6.157 & 0.767 & 1.413 & 1.015 \\
$\mathrm{IEC}$ & 99.102 & 88.700 & 7.900 & 301.100 & 76.986 & 0.777 & 0.829 & 0.215 \\
$\mathrm{IMP}$ & 66.822 & 80.300 & 10.000 & 140.000 & 40.327 & 0.603 & 0.009 & -1.194 \\
LEN & 13.564 & 13.540 & 6.000 & 31.700 & 6.681 & 0.492 & 0.497 & -0.787 \\
CAS & 0.011 & 0.007 & $5.4 \mathrm{e}-005$ & 0.042 & 0.010 & 0.966 & 1.052 & 0.445 \\
EXD & 0.305 & 0.199 & 0.012 & 1.116 & 0.346 & 1.135 & 1.110 & -0.085 \\
EXR & 0.094 & 0.064 & 0.009 & 0.313 & 0.086 & 0.916 & 0.999 & -0.039 \\
NOI & 0.192 & 0.189 & 0.073 & 0.315 & 0.058 & 0.301 & 0.180 & -0.726 \\
\hline
\end{tabular}

Source: Computed by authors and variables are as defined in equation 6 .

Table 2 - ADF-GLS Unit Root test Results for Variables Used in the Analysis

\begin{tabular}{|c|c|c|c|c|c|c|}
\hline \multirow{2}{*}{$\begin{array}{l}\text { Logged } \\
\text { Variables }\end{array}$} & \multicolumn{5}{|c|}{ ADF-GLS Unit Root Test } & \\
\hline & Level & 1st diff. & OT & Level & 1st diff. & OT \\
\hline $\mathrm{LnHCl}_{\mathrm{t}}$ & -2.087 & $-7.560^{\star \star \star}$ & $1(1)$ & -1.414 & $-7.450 * * *$ & $1(1)$ \\
\hline $\mathrm{LnOCl}_{\mathrm{t}}$ & -3.216 & $-9.761^{* * *}$ & $1(1)$ & $-2.734^{\star \star *}$ & - & $1(0)$ \\
\hline $\mathrm{LnECl}_{\mathrm{t}}$ & -0.886 & $-8.332^{\star \star \star}$ & $1(1)$ & -2.275 & $-9.874^{\star * *}$ & $1(1)$ \\
\hline $\mathrm{LnCOP}_{\mathrm{t}}$ & -2.257 & $-7.652^{\star \star \star}$ & $1(1)$ & 1.484 & $-7.010^{\star * *}$ & $1(1)$ \\
\hline $\operatorname{LnPCG}_{t}$ & -1.468 & $-5.140 * \star *$ & $1(1)$ & 2.312 & $-4.691^{* * *}$ & 1(1) \\
\hline $\operatorname{LnINF}_{t}$ & -3.520 & $-7.723^{\star \star \star}$ & $1(1)$ & -2.492 & $-7.712^{\star \star \star}$ & 1(1) \\
\hline $\operatorname{LnFDA}_{t}$ & -3.060 & $-9.261^{\star * *}$ & $1(1)$ & -0.607 & $-9.212^{\star * *}$ & 1(1) \\
\hline LnUEM $_{t}$ & -2.110 & $-7.928^{* * *}$ & $1(1)$ & -0.496 & $-6.905^{\star * *}$ & $1(1)$ \\
\hline LnIEC $_{t}$ & -1.522 & $-6.379^{* \star *}$ & $1(1)$ & 0.614 & $-6.319^{\star * *}$ & 1(1) \\
\hline $\operatorname{LnIMP}_{\mathrm{t}}$ & -1.494 & $-8.016^{\star \star \star}$ & $1(1)$ & 0.381 & $-7.704^{\star \star \star}$ & 1(1) \\
\hline $\operatorname{LnLEN}_{\mathrm{t}}$ & -1.699 & $-7.241^{\star \star \star}$ & 1(1) & -0.638 & $-7.259^{\star \star \star}$ & 1(1) \\
\hline $\operatorname{LnCAS}_{t}$ & -0.094 & $-7.861^{\star \star \star}$ & 1(1) & -0.873 & $-4.754^{\star \star \star}$ & 1(1) \\
\hline $\operatorname{LnEXD}_{\mathrm{t}}$ & -1.844 & $-9.069^{\star \star \star}$ & 1(1) & -1.563 & $-8.941^{* * *}$ & 1(1) \\
\hline $\operatorname{LnEXR}_{t}$ & -3.259 & $-8.042^{\star \star \star}$ & $1(1)$ & -1.931 & $-7.995^{\star * *}$ & 1(1) \\
\hline $\mathrm{LnNOI}_{\mathrm{t}}$ & -3.410 & $-11.013^{\star \star \star}$ & 1(1) & -2.048 & $-10.823^{\star * *}$ & 1(1) \\
\hline $1 \%$ & -3.755 & -3.758 & & -2.608 & -2.609 & \\
\hline
\end{tabular}


Note: OT means order of integration. Critical values (CV) are defined at $1 \%$ significant level and asterisks *** represents $1 \%$ significance level. Variables are as defined previously in equation 6.

Unit Root test of Variables used in the Analysis. The ADF-GLS test result revealed that at level, all specified variables were non stationary, but were stationary at first difference. The critical value was kept at $1 \%$ significant level to ensure the best result. The result of the ADFGLS unit root test implies that, the analysis of the specified variables at their levels could result in spurious regression estimates. This indicates that, the variables should be tested for the presence of co-integration and Error Correction mechanism (Johansen, 1988 and Johansen and Juselius, 1990). The essence of the exercise was to reduce the incidence of spurious regression and thus unreliable estimates in the analysis.

Result of the Trend Analysis of Agricultural Intensification Index in Nigeria (1960 2014). Estimates of the exponential trend equation for $\mathrm{HCl}, \mathrm{OCl}$ and $\mathrm{ECl}$ are presented in Table 3. The result revealed that, all agricultural intensification index exhibited significant negative relationship with time in Nigeria. This means that, the agricultural intensification index decreases as year increases. For instance, the $\mathrm{HCl}$ declines by $1.60 \%$ per annum. Similarly, $\mathrm{OCl}$ and $\mathrm{ECl}$ indices depreciated by $2.10 \%$ and $0.10 \%$ per annum respectively. These results indicated that, agricultural sector share in the country's GDP declined relative to other sectors' share. Alternatively, the significant of agricultural sector in the country's GDP showed accumulative declined in the study period using the three measures of agricultural intensification. The result revealed that, the country is gradually moving away from heavy investment in agriculture to other sectors. Furthermore, it means that, the productivity and income from the manufacturing sector, service sector, whole sale and retail trades as well as the building and construction sectors have increase faster than the agricultural sector. This result further revealed that, the diversification drive of the federal government as embedded in various development programmes and policies are gradually yielding positive results. As part of the transformation agenda, the federal government including the second and third tiers of governments has invested resources in the development of informal sector; they have also provided social infrastructures and institutional frameworks on which a sound private driven economy could rest on. These gestures help increase contributions of other non-oil sectors in the country GDP while contribution from agricultural sector assumes progressive declined.

Table 3 - Exponential Trend Analysis of Agricultural intensification index in Nigeria

\begin{tabular}{llll}
\hline Variables & \multicolumn{1}{c}{ LnHCI } & \multicolumn{1}{c}{ LnOCI } & \multicolumn{1}{c}{ Ln ECI } \\
\hline Constant & $-1.579(-11.15)^{\star * \star}$ & $-1.776(-3.533)^{\star * *}$ & $0.249(80.070)^{\star * *}$ \\
Time & $-0.016(-3.573)^{\star * *}$ & $-0.021(-1.358)$ & $-0.001(-7.677)^{\star \star *}$ \\
F- cal. & $12.768^{\star \star *}$ & 1.8445 & $58.930^{\star \star *}$ \\
R-square & 0.194 & 0.034 & 0.526 \\
Exp. GR (\%) & -1.60 & -2.10 & -0.10 \\
\hline
\end{tabular}

Note: Values in bracket represent $t$-values. The asterisk ${ }^{* *}$ represents $1 \%$ significance level.

To further substantiate the trend behaviour of agricultural intensification index in Nigeria, figure 1 shows the linear trend graphs of $\mathrm{HCl}$ and $\mathrm{OCl}$; while figure $1 \mathrm{~b}$ presents that of ECl. The three indexes of agricultural intensification assumed the highest values in 1960 . During this period, agricultural sector provided the only viable source of income to the country. Thereafter, it is observed that, $\mathrm{HCl}$ and $\mathrm{OCl}$ as well as $\mathrm{ECl}$ persistently trended downward from the highest value in 1960 to the trough value in 1974 and remained at the trough till 1980 for $\mathrm{HCl}$ and $\mathrm{OCl}$. These downward trends in the estimated indexes were largely attributed to the increase in crude oil earnings of this period. The period was characterised by restrictive or regulated economic policies. It witnessed more direct government intervention in agriculture in the face of the noticeable declined in agriculture performance. Also, the import substitution industrialization policy of this era provided effective protection to the local manufacturing industries, through such measures as quantitative restrictions and high import duties on finished goods (Ogun, 1987). The 
exchange rate policy became protectionist and by 1972 the domestic currency was overvalued. Following the implementation of these policies, the rate of growth of import fell and competition between foreign and domestic firms manufactures reduced; consequently domestic industrial activities witnessed an impressive growth. During this period, the country's economy shifted from agrarian to crude oil based economy. The contribution of agricultural sector in the GDP declined progressively. Thus, the agricultural sector was almost neglected and while diversification received an impressive but unsustainable boom (CBN, 2005 and Udoh and Elias, 2011).

The fluctuations in $\mathrm{HCl}$ and $\mathrm{OCl}$ witnessed an average upward trend in the period 1980 to 1990 . This period was marked with a significant moderation in the economic environment and industrial policies in Nigeria. Imbalances in both internal and external economy structures prevailed in the country. As a consequence, the output of the industrial sector shrinks (Nwosu, 1992). This period ushered in the Structural Adjustment Programme (SAP) and subsequent liberalization of the Nigerian economy. It marked the beginning of a deregulated economy. Exchange rate deregulation was the major policy instrument. Several agricultural policies were implemented to revive the country's economy. During the early part of this period, agricultural intensification mounted but declined towards 1990. Thereafter, the agricultural intensification indices showed undulated trend till 2014. It is observed that, these fluctuations were consonance with government policies and interest in agricultural activities.

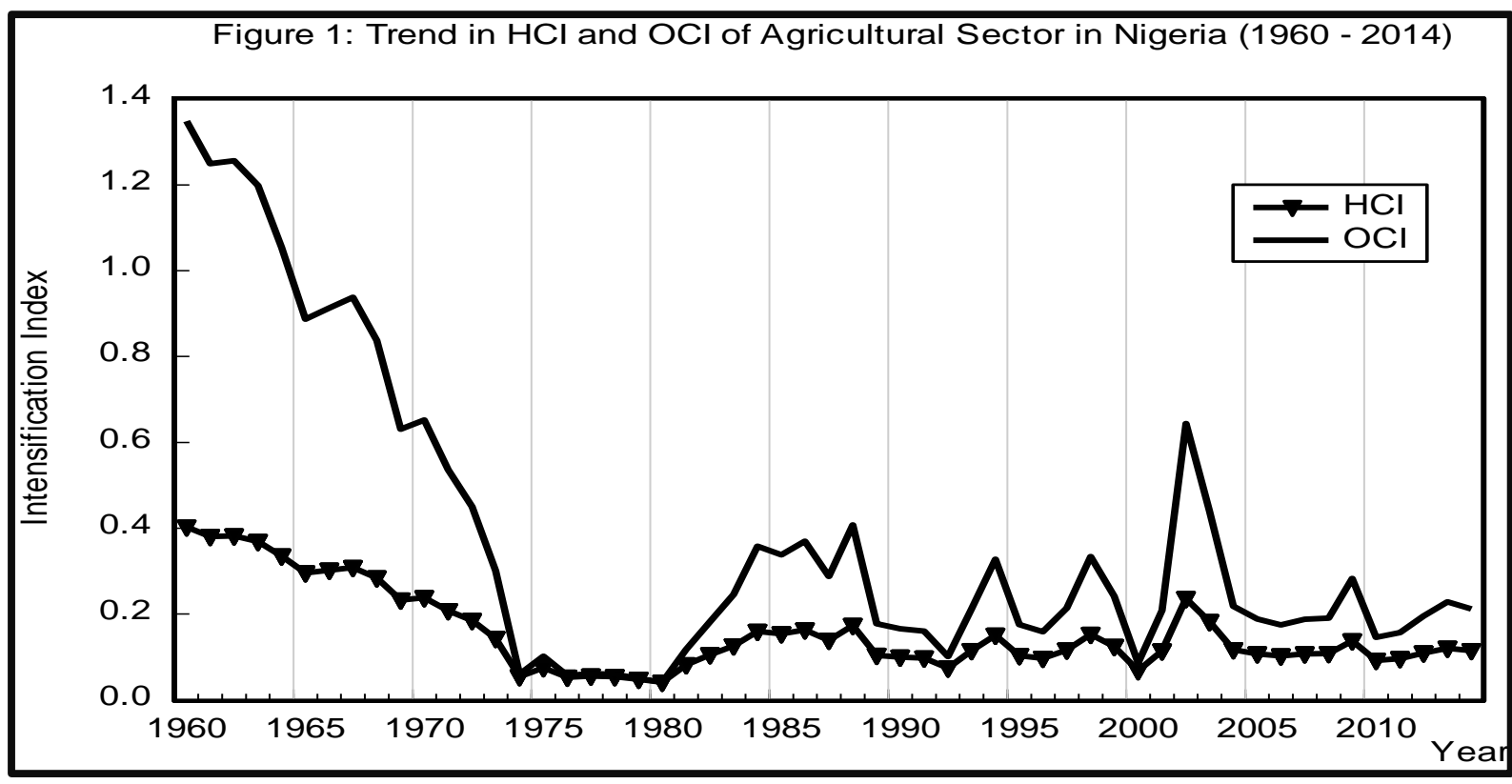

For instance, the policy thrust of the National Economic Empowerment Development Strategy (NEEDS), National Agricultural Policy (NAP) and Rural Sector Strategy (RSS) in 2004 help shape the pattern of fluctuation in all the three indexes of agricultural intensification in Nigeria. The overall strategic objective of the NEEDS and NAP was to diversify the productive base from oil to non-oil sectors and promote market-oriented and private sector-driven economic development with strong local participation. The Nigerian civilian government that commenced towards the end 1990's has, in addition to the aforementioned policies, initiated and endorsed many national and international projects, programs, and policies aimed at rapid agricultural growth. These include the implementation of the Comprehensive Africa Agriculture Development Program (CAADP), the National Food Security Program (NFSP), the Agriculture 5-point Agenda, (Diao et al., 2010). Recent developments, therefore, suggest that Nigeria's greatest desire was to carry out economic transformation and increase economic growth by reviving and restructuring her neglected agricultural sector. Though $\mathrm{HCl}$ and $\mathrm{OCl}$ expressed the trough-depressions in 2000, it however recovered and later moved above the depression point in undulated manner till 
2014. However, the trend in $\mathrm{ECl}$ underwent almost similar displayed like $\mathrm{HCl}$ and $\mathrm{OCI}$ during the study period.

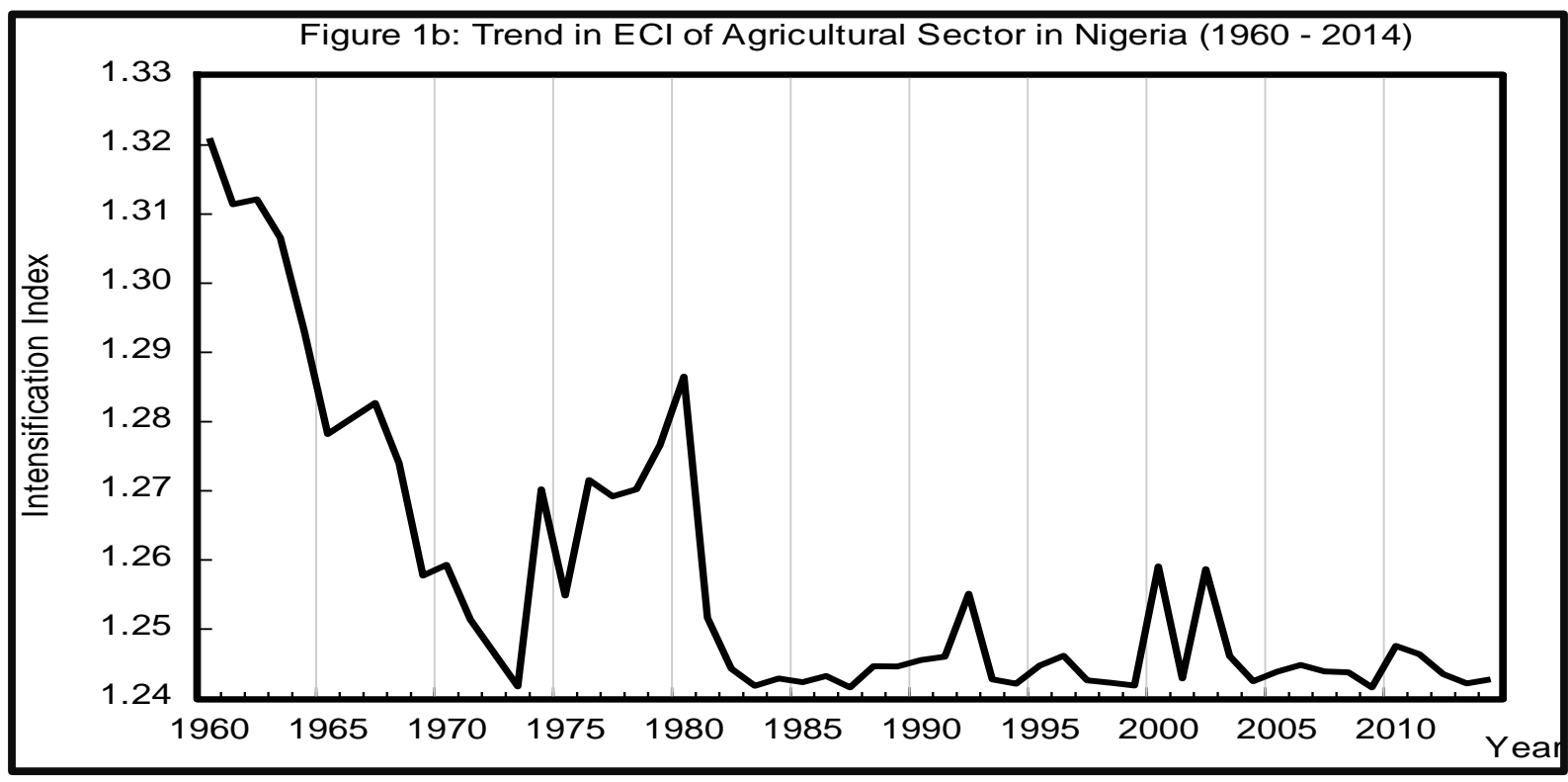

The fluctuation in $\mathrm{ECl}$ was also consistent with various policies implemented in the country during the study period. In summary, $\mathrm{HCl}, \mathrm{OCl}$ and $\mathrm{ECl}$ have showed step-like declined from 1960 to early 1970s. Thereafter, the indexes assumed short peaks and troughs in response to government intervention policies. For instance, the peaks coincided with the positive response while the troughs represent the opposite behavior. On average, the estimated indexes trended downward in most period investigated.

Result of Co-integration Test for Agricultural Intensification Index in Nigeria. The study applied the Engle and Granger two-step technique and Johansen cointegration approach to examine the co-integration relationship among the specified time series.

Table 4 - Long run estimates of Agricultural intensification equations

\begin{tabular}{|c|c|c|c|}
\hline Variables & $\mathrm{HCl}$ & $\mathrm{OCl}$ & $\mathrm{ECl}$ \\
\hline $\begin{array}{l}\text { Constant } \\
\text { COP }_{t} \\
\text { PCG }_{t} \\
\text { INF }_{t} \\
\text { FDI }_{t} \\
\text { UEM }_{t} \\
\text { IEC }_{t} \\
\text { IMP }_{t} \\
\text { LEN }_{t} \\
\text { CAS } \\
\text { EXD }_{t} \\
\text { EXR }_{t} \\
\text { NOI }_{t}\end{array}$ & $\begin{array}{l}-1.853(-1.290) \\
0.034(0.229) \\
0.117(0.969) \\
-0.200(-3.449)^{\star * *} \\
-0.090(-1.247) \\
-0.051(-0.333) \\
0.403(1.418) \\
-1.179(-4.882)^{\star * *} \\
0.702(2.657)^{\star *} \\
-0.081(-1.243) \\
0.139(2.267)^{\star \star} \\
-0.345(-5.632)^{\star * \star} \\
0.070(0.536)\end{array}$ & $\begin{array}{l}-1.882(-0.305) \\
0.173(0.274) \\
0.727(1.407) \\
-0.638(-2.557)^{\star *} \\
-0.636(-2.050)^{\star *} \\
-0.786(-1.202) \\
1.876(1.621) \\
-4.560(-4.400)^{\star * *} \\
2.473(2.182)^{\star *} \\
-0.135(-0.478) \\
0.516(1.965)^{\star} \\
-1.277(-4.859)^{\star * *} \\
0.059(0.105)\end{array}$ & $\begin{array}{l}0.359(8.409)^{\star * \star} \\
0.015(3.412)^{\star \star *} \\
-0.018(-4.914)^{\star \star *} \\
0.0002(0.137) \\
0.005(2.493)^{\star *} \\
-0.002(-0.440) \\
-0.011(-2.153)^{\star *} \\
-0.003(-0.390) \\
-0.009(-1.271) \\
-0.003(-1.377) \\
-0.002(-1.270) \\
0.002(1.104) \\
0.009(2.242)^{\star *}\end{array}$ \\
\hline $\begin{array}{l}\text { R- Square } \\
\text { F-Cal. } \\
\text { LM (autocorrelation) } \\
\text { RESET test } \\
\text { DWatson }\end{array}$ & $\begin{array}{l}0.849 \\
19.808^{\star \star \star} \\
0.006 \\
1.311 \\
1.972\end{array}$ & $\begin{array}{l}0.737 \\
9.784^{\star \star \star} \\
3.747^{\star} \\
12.385^{\star \star \star} \\
2.526\end{array}$ & $\begin{array}{l}0.839 \\
18.257^{\star * *} \\
0.758 \\
20.044^{\star * \star} \\
1.738\end{array}$ \\
\hline $\begin{array}{l}\text { ADF-GLS unit root te } \\
\text { Constant } \\
\text { Constant + trend }\end{array}$ & $\begin{array}{l}\text { errors generated } \\
-6.667^{\star \star \star} \\
-7.057^{\star \star \star}\end{array}$ & $\begin{array}{l}\text { e equations } \\
-9.526^{\star * *} \\
-9.524^{\star \star *}\end{array}$ & $\begin{array}{l}-5.768^{\star \star \star} \\
-6.168^{\star \star \star}\end{array}$ \\
\hline
\end{tabular}

Note: Variables are expressed in logarithm. Figures in bracket are t-tests. Asterisks * ${ }^{* *}$ and ${ }^{* *}$ represents $10 \%$, $5 \%$ and $1 \%$ significance level respectively. 
The result of the Engle and Granger two-step technique of cointegration test for each of the estimated index is presented in the lower portion of the respective equation in Table 4. The results showed that at $1 \%$ significance level of the critical value, the Engle-Granger cointegration tests rejected the null hypothesis of no cointegration in equations involving the three indexes. The result suggested that, there are long run stable equilibrium relationships between the agricultural intensification indexes and the specified macroeconomic variables in Nigeria. The results showed that at $1 \%$ probability level of significance, the Augmented Dicker-Fuller -GLS (ADF-GLS) unit root test for the residuals at level is greater than the critical value at $1 \%$ probability level.

For the Johansen co-integration test approach, the tabulated trace and maximum eigenvalue test statistics were significant at various levels of significant. The result as presented in Table 5 revealed that the calculated trace test and maximum eigenvalue test statistics are greater than the critical values at various conventional probability levels.

The result showed that, there are more than one co-integration equations among specified variables. This implies that, the agricultural intensification indexes will fluctuate to a stable state in the long run following short run fluctuation in some macroeconomic variables in Nigeria. However, the upper portion of Table 4 contained the long run estimates for the individual agricultural intensification index equation. The estimated coefficients represent the long run agricultural intensification index elasticity with respect to each specified macroeconomic variable in the model.

Table 5 - Johansen Cointegration Test Results

\begin{tabular}{|c|c|c|c|c|c|c|}
\hline \multicolumn{2}{|c|}{$\begin{array}{l}\text { Hypotheses } \\
\text { (Null) (Alternative) }\end{array}$} & Eigenvalue & $\begin{array}{l}\text { Trace } \\
\text { Statistic }\end{array}$ & $\begin{array}{l}0.05 \\
\text { Critical Value }\end{array}$ & $\begin{array}{l}\text { Max-Eigen } \\
\text { Statistic }\end{array}$ & $\begin{array}{l}0.05 \\
\text { Critical Value }\end{array}$ \\
\hline$r=0$ & $r \geq 1$ & 0.974 & 927.338 & - & 194.943 & - \\
\hline$r \leq 1$ & $r \geq 2$ & 0.946 & 732.395 & 334.984 & 155.042 & 76.578 \\
\hline$r \leq 2$ & $r \geq 3$ & 0.916 & 577.353 & 285.143 & 130.978 & 70.535 \\
\hline$r \leq 3$ & $r \geq 4$ & 0.874 & 446.376 & 239.143 & 109.786 & 64.505 \\
\hline$r \leq 4$ & $r \geq 5$ & 0.832 & 336.589 & 197.371 & 94.453 & 58.433 \\
\hline$r \leq 5$ & $r \geq 6$ & 0.747 & 242..136 & 159.529 & 72.792 & 52.363 \\
\hline$r \leq 6$ & $r \geq 7$ & 0.645 & 169.344 & 125.615 & 54.836 & 46.231 \\
\hline
\end{tabular}

Note: Trace test indicates more than one co-integrating equations at $5 \%$ significant level. MacKinnon-HaugMichelis (1999) p-values.

Generating Optimal Lag- Length for the Co-Integrating Variables. Appropriate lag length for the co-integrating series is needed to generate the error correction model (ECM) for the co-integrating variables. The Akaike criterion (AIC), Schwarz Bayesian criterion (BIC) and Hannan- Quinn criterion (HQC) test were employed to determine the appropriate lag length. The test result as shown in Table 6 indicates that the optimum lag length appropriate for generating the ECM is at lag one.

Table 6 - Determination of Optimum Lag length

\begin{tabular}{llllll}
\hline Lag & Loglike & $\mathrm{P}(\mathrm{LR})$ & $\mathrm{AIC}$ & $\mathrm{BIC}$ & $\mathrm{HQC}$ \\
\hline 1 & 137.442 & - & -3.5777 & -1.7421 & $-2.8787^{*}$ \\
2 & 148.358 & 0.0094 & -3.6543 & -1.4746 & -2.8243 \\
3 & 158.483 & 0.0164 & -3.6993 & -1.1755 & -2.7382 \\
4 & 168.819 & 0.0142 & -3.7528 & -0.8848 & -2.6606 \\
\hline
\end{tabular}

The asterisks below indicate the best (that is, minimized) values of the respective information criteria, $A I C=$ Akaike criterion, $B I C=$ Schwarz Bayesian criterion and HQC = Hannan-Quinn criterion.

Error Correction Model for Agricultural Intensification Indexes in Nigeria. The primary reason for estimating the ECM model was to capture the dynamics in the agricultural intensification index equations and identify the speed of adjustment as a response to departure from the long-run equilibrium. The study adopted Hendry's (1995) approach in 
which an over parameterized model is initially estimated and then gradually reduced by eliminating insignificant lagged variables until appropriate ECM model is obtained. The result of the exercise is presented in Tables 7. The slope coefficient of the error correction term in each equation is negative and statistically significant at conventional levels of probability. This result is in line with a priori expectation. The result validates the existence of a stable long-run equilibrium relationship among the time series in $\mathrm{HCl}$ and $\mathrm{ECl}$ equations, and also indicates that the indexes are sensitive to the departure from their equilibrium value in the previous periods. The result assumed that, the adjustment mechanism of the error correction term is linear and symmetric. This means that, the adjustment speed in HCL equation is the same no matter the shock in the specified macroeconomic variables. The same implication is also applied to $\mathrm{ECl}$ equation. On the other hand, the result showed an explosive long run model in $\mathrm{OCl}$ equation, that is the $\mathrm{ECM}$ coefficient is greater than unity $\left(\mathrm{ECM}_{\mathrm{t}}>1\right)$. It implies that, the fluctuation in $\mathrm{OCl}$ equation did not result in long run stability or did not conformed to Engle Granger symmetric cointegration test. This implies that, reliable and short run inferences cannot be obtained from $\mathrm{OCl}$ equation using Engle Granger test. Hence, at this point, it is recommended that, asymmetric cointegration test should be conducted for $\mathrm{OCl}$ and macroeconomic variable in Nigeria. Preferably, the use of the Threshold Autoregressive (TAR) cointegration model and Momentum-Threshold Autoregressive (M-TAR) cointegration models should be used.

The slope coefficient of the error correction term in $\mathrm{HCl}$ and $\mathrm{ECl}$ equation represent the speed of adjustment and also is consistent with the hypothesis of convergence towards the long-run equilibrium once the respective equation is disturbed. The diagnostic test for the $\mathrm{ECM}$ model revealed $\mathrm{R}^{2}$ value of 0.677 for $\mathrm{HCl}$ and 0.594 for $\mathrm{OCl}$ equations. The DurbinWatson and Lagrange Multiplier values for each equation indicate insignificant effect of serial correlation. The ECM model has been shown to be robust against residual autocorrelation. Therefore, the presence of autocorrelation does not affect the estimates (Laurenceson and Chai, 2003).

Table 7 - Short run estimates of Agricultural intensification equations

\begin{tabular}{|c|c|c|c|}
\hline Variables & $\mathrm{HCl}$ & $\mathrm{OCl}$ & $\mathrm{ECl}$ \\
\hline Constant & $0.065(1.460)$ & $0.302(1.418)$ & $-0.003(-1.913)^{*}$ \\
\hline$\Delta \mathrm{LnHClt}-1$ & $0.184(1.456)$ & - & - \\
\hline$\Delta \mathrm{Ln}$ OClt-1 & - & $0.102(0.795)$ & - \\
\hline$\Delta$ Ln EClt-1 & - & - & $0.026(0.187)$ \\
\hline$\Delta \mathrm{Ln}$ COPt & $-0.213(-1.618)$ & $0.457(0.742)$ & $0.007(1.769)^{*}$ \\
\hline$\Delta \mathrm{Ln} P \mathrm{PCG}_{\mathrm{t}}$ & $-0.237(-1.013)$ & $-1.681(-1.497)$ & $0.004(0.607)$ \\
\hline$\Delta \mathrm{Ln} \mathrm{INF}_{\mathrm{t}}$ & $-0.094(-2.054)^{\star *}$ & $-0.336(-1.600)$ & $-0.002(-1.832)^{*}$ \\
\hline$\Delta \mathrm{Ln} \mathrm{FDI}_{\mathrm{t}}$ & $-0.075(-1.421)$ & $-0.353(-1.400)$ & $0.002(1.031)$ \\
\hline$\Delta \operatorname{Ln} \cup M_{t}$ & $0.087(0.650)$ & $-0.768(-1.198)$ & $0.0002(0.055)$ \\
\hline$\Delta \mathrm{Ln}$ IEC & $0.291(1.604)$ & $0.908(1.030)$ & $-0.007(-1.303)$ \\
\hline$\Delta \mathrm{Ln} \mathrm{IMP}_{\mathrm{t}}$ & $-0.535(-2.170)^{\star *}$ & $-3.085(-2.680)^{\star \star}$ & $0.0004(0.054)$ \\
\hline$\Delta \operatorname{Ln~LEN~}_{t}$ & $0.392(1.726)^{*}$ & $1.494(1.378)$ & $0.002(0.336)$ \\
\hline$\Delta \mathrm{Ln} \mathrm{CAS}_{\mathrm{t}}$ & $-0.027(-0.466)$ & $-0.099(-0.365)$ & $-0.001(-0.896)$ \\
\hline$\Delta \operatorname{Ln} \mathrm{EXD}_{\mathrm{t}}$ & $0.063(1.366)$ & $0.359(1.628)$ & $-0.002(-1.229)$ \\
\hline$\Delta \mathrm{Ln} \mathrm{EXR}_{\mathrm{t}}$ & $-0.186(-2.727)^{\star \star \star}$ & $-1.158(-3.894)^{\star * \star}$ & $-0.0001(-0.076)$ \\
\hline$\Delta \mathrm{Ln} \mathrm{NOI}{ }_{\mathrm{t}}$ & $0.124(1.195)$ & $0.530(1.054)$ & $-0.002(-0.561)$ \\
\hline ECMt-1 & $-0.837(-4.829)^{* * *}$ & $-1.256(-6.396)^{* * *}$ & $-0.630(-4.268)^{* * *}$ \\
\hline R-Square & 0.677 & 0.719 & 0.590 \\
\hline F-cal & $5.705^{\star \star \star}$ & $6.929^{* * *}$ & $3.908^{\star \star \star}$ \\
\hline DW test & 1.829 & 1.761 & 1.794 \\
\hline $\operatorname{LM}(1)$ & 0.772 & 2.791 & 1.594 \\
\hline Normality (error) & $5.141^{*}$ & $45.032^{* \star *}$ & 1.757 \\
\hline
\end{tabular}

Note: Variables are expressed in logarithm Asterisks * ${ }^{* *}$ and ${ }^{* * *}$ represents $10 \%, 5 \%$ and $1 \%$ significance level respectively. 
Long run and short run Elasticity of agricultural Intensification with Respect to Macroeconomic Variables in Nigeria. The Long run model results from "HCl" and "ECl" revealed that, agricultural intensification has significant negative relationship with inflation rate (INF), manufacturing capacity (IMP), external reserves (EXR), energy consumption (IEC) and per capita income (PCG) in Nigeria. The result implies that, these macroeconomic variables are probable negative drivers of agricultural intensification in Nigeria. For instance, increase in inflation will lower the real income of farmers and raise the nominal price of farm resources through the spilled over or multiplier effects thereby discouraging investment in the sector. It is known that, the supply of most agricultural commodities are elastic, while demand remains inelastic, hence during period of high inflation, most farmers will diversify to non-farming activities due to low real income. Also, low income earners will have low purchasing power during period of high inflation. Following the low of demand and supply, this action will force down the price of most agricultural commodities especially perishable ones during period of intense inflation. This result is in line with similar findings reported by Sunday et al., (2012); Olarinde and Hussainatu 2014 and Akpan and Inimfon (2015) in Nigeria. Also, Gardener (1981) and Tangermann and Heihues (1973) noticed similar relationship in US and Europe respectively.

In a similar way, the result of the relationship between agricultural intensification and index of manufacturing production connotes that; increase in industrial production decreases the agricultural intensification drive in the economy. Increase in industrial production has ability to stimulate a multiplier chain in job generation. Since agricultural sector is labour intensive and mostly practiced in small scale basis, surplus labour force (mostly youth) in the sector is easily trapped in industrial activities, thereby stimulating massive job diversification from agricultural sector among youthful population. A significant shortage in human labour will reduce intensification drive in the sector.

Agricultural intensification index also exhibited negative correlation with external reserves in Nigeria. Increase in external reserves could means that, the domestic economy does not have sufficient investment opportunities. Since Nigeria is basically an agrarian society, increase in external reserves will implies that, the government has not invested sufficiently in agricultural sector. Alternatively, it implies that the government has not generated sufficient opportunities for investment in the sector; or there are sufficient and more rewarding investments opportunities in other sectors of the country's economy. Following this, the economy will re-adjust to stimulate investment in other sectors (or more productive sectors) while disinvesting in agricultural sector. Sunday et al. (2012) have also noticed this relationship earlier using index of agricultural productivity in Nigeria.

The per capita income, that proxy economy improvement fluctuates in opposite direction as agricultural intensification. Increase in per capita GDP means increase in the consumers' real income, purchasing power and preference/choice as well as utility. Since consumers are considered to be rational, they will prefer good, quality and cheap as well as more satisfying foreign agricultural commodities if their demand capabilities increase. Following this, the real income of the domestic farmers will shrink, leading to lower production and subsequent diversification tendencies in the long run.

The result also showed that, increase in electricity consumption decreases agricultural intensification in Nigeria. The result satisfies a priori expectation, because increase in energy consumption will trigger small scale businesses and facilitate food processing and value addition. Agricultural production has a long gestation period and young people will prefer fast yielding businesses to agricultural activities. Hence, increase in energy consumption will lead to exodus of young vibrant labour from agricultural sector to the informal farmers. Thus without sufficient incentives and sound policy frame work and institutions, continuous increase in energy consumption in the country will result in a continuous decrease in agricultural intensification in the long run. Akpan and Inimfon (2015) have reported similar result for palm oil, palm kernel and rubber output in Nigeria.

On the other hand, the coefficient of crude oil price (COP), commercial Bank lending rate (LEN), external debt (EXD), foreign direct investment in agriculture (FDI) and non-oil imports (NOI) exhibited positive relationships with agricultural intensification in Nigeria. The 
result implies that, as crude oil price increases, agricultural intensification increases. This is because most of the country's real sector policies focused on agricultural production; hence increase in oil price implied increase in the country's revenue and probably increment in agricultural investment. This situation increases agricultural intensification and reduce diversification too.

Also, increase in the lending rate of commercial Banks increases agricultural intensification in several ways. Increase in the lending rate of Banks reduces the accessibility to agricultural credit by farmers. Since most farmers in the country do not have sufficient collateral to obtain loan, thus a rise in lending rate will discourage commercial farming and promote subsistence farming. Subsistence farming is linked to farm resource intensification and increase rural-urban youth migration. In addition, mounting external debt in a country is an indication for intensification of sectors in which the country has comparative advantage.

Similarly increase in foreign direct investment in agricultural sector has a direct link with agricultural intensification in Nigeria. This implies that, as FDI increases, the mechanization of agricultural activities is boosted too. Significant portion of agricultural activities will become mechanized (e.g. in poultry production) and specialization will be promoted. Increase specialization in agricultural sector implies increase intensification in the sector. This result implies that, as a way to increase agricultural intensification, policies and programmes aimed at increasing foreign capital inflow into agricultural sector should be pursuit vigorously. Eyo (2008) obtained similar result using proportion of agricultural income in GDP. Msuya (2007) also found positive relationship between foreign direct investment and agricultural output growth in Tanzania.

Furthermore, the long run model revealed that, the coefficient of non-oil import exhibited significant positive influence on agricultural intensification in Nigeria. The result satisfies a priori expectation, as increase in sustainable non-oil imports will stimulate domestic competition in agricultural sector. With good import policies in the country and sufficient incentives to agricultural sector, increase in non-oil import can create a competitive environment for farmers in the country. One of the most popular strategies used by farmers to safe guard the domestic agricultural market is to intensify production. When agricultural production is intensified, output will increase and price is guaranteed to fall. The fall in price will check the demand of imported agricultural commodity and discouraged importation in the long run. This assumption only works if other factors that, affect demand are held constant.

Result of the short run Model of Agricultural Intensification in Nigeria.The short run elasticity coefficient revealed that, inflation rate (INF); manufacturing output (IMP) and external reserves (EXR) have significant short run negative relationship with agricultural intensification in Nigeria. This means that, in the short run, these macroeconomic variables are negative drivers of agricultural intensification in Nigeria.

On the other hand, the lending rate of commercial Banks (LEN) and crude oil price (COP) exhibited positive correlation with agricultural intensification in the short run. The result on the lending rate could be due to poverty and corruption that engulfed most farmers and credit institutions in the country respectively. In Nigeria, good number of beneficiaries of government agricultural credit schemes are non-farmers who do not considered the interest charge on such loan facilities. Due to lack of collateral, the activities of the real farmers who are mostly poor will not be determined by the fluctuation in interest rate of Banks. Hence, agricultural intensification which is usually linked to farmers' subsistence nature will continue even in the face of high lending rate from commercial Banks.

The crude oil price also impacted positively on agricultural intensification in the short run in Nigeria. This means, agricultural sector had been one of the priority sectors of the federal government of Nigeria both in the short and long run periods.

A ten-year out sample Forecast of Agricultural Intensification Indexes in Nigeria (2015 to 2024). A ten-year trend forecast of $\mathrm{HCl}, \mathrm{OCl}$ and $\mathrm{ECl}$ is shown in Figure 2 to Figure 4 respectively. The diagrams showed progressive downward trend in agricultural intensification indexes in Nigeria. This means that, by stabilizing movement in macroeconomic variables as well as other important variables in the Nigeria's economy, agricultural intensification will declined relative to others sectors in the next ten years. Alternatively, the contribution of 
agricultural sector in the country GDP's will witnessed a steady declined relative to other sector in the economy.

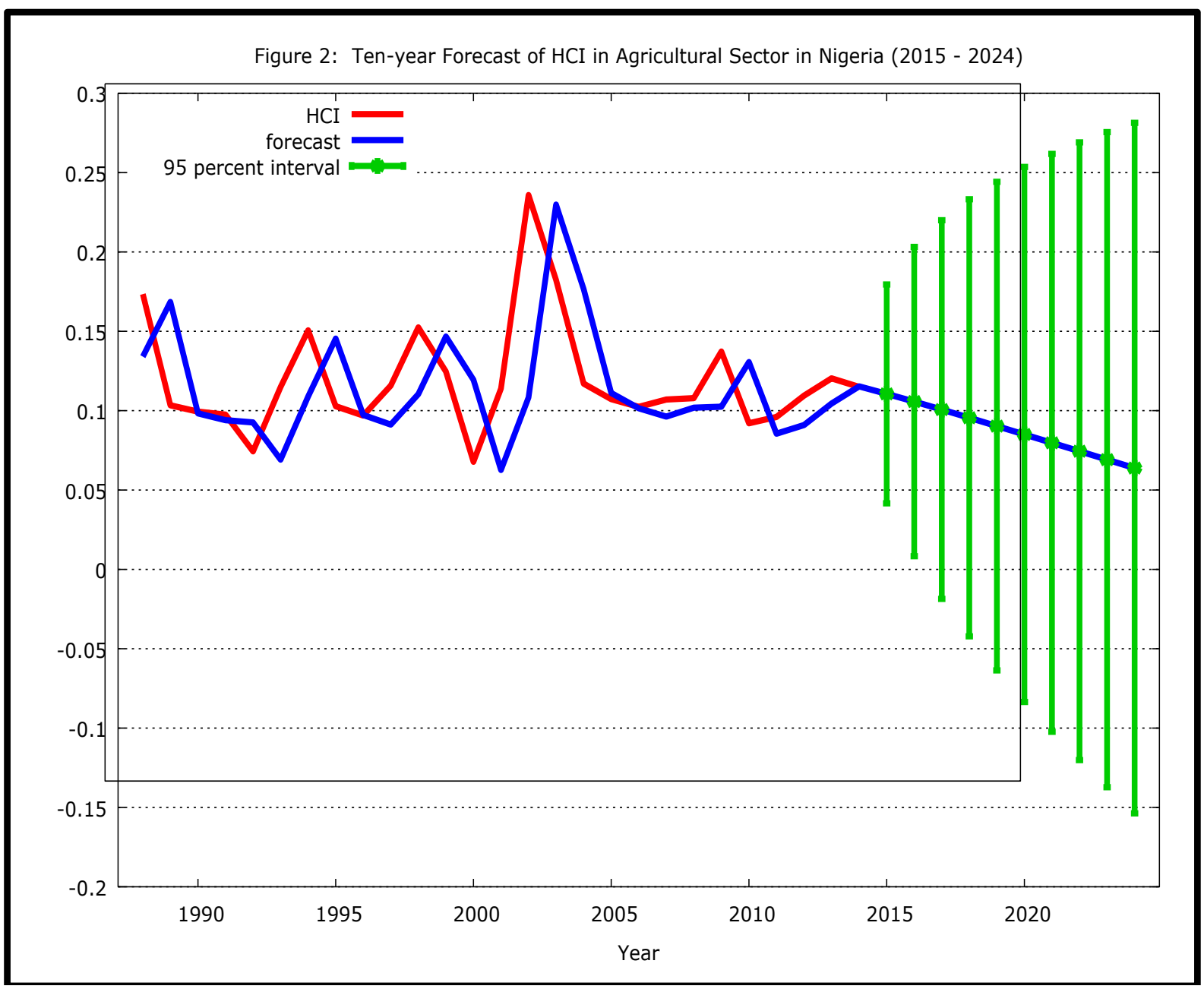

The pattern of forecasted growth in the three indexes is similar and moved downward steadily from 2015 to 2024. This result connotes that, citeris paribus; the country will experienced reduce growth of agricultural sector than growth in industrial sector, service, building and construction as well as the whole sale and retailed trade sectors. It means that, the contribution of these sectors to the country's GDP will likely witnessed progressive boom in the period 2015 to 2024 if stability in macroeconomic variables among others is achieved. The confidence intervals showed a two-sided steady growth from 2015 to 2024 . This means that, the country agricultural intensification indexes are capable of trending more downward or upward depending on the economic situation in the country. This indicates that, if sound macroeconomic policies are implemented, the economy is capable of tilting away from the dominancy of agricultural sector among non-oil sectors in the GDP to other sectors. The result has a lot of implications on the current and future economy plans for the government of Nigeria. It implies that, there are viable potentials outside agricultural sector to grow the economy to achieve the long term objective of industrialization and poverty reduction. Whatever the growth pattern in agricultural sector, the result implies that, others sectors that contributed to the country GDP will increase their shares given stable economic environment in the country. 


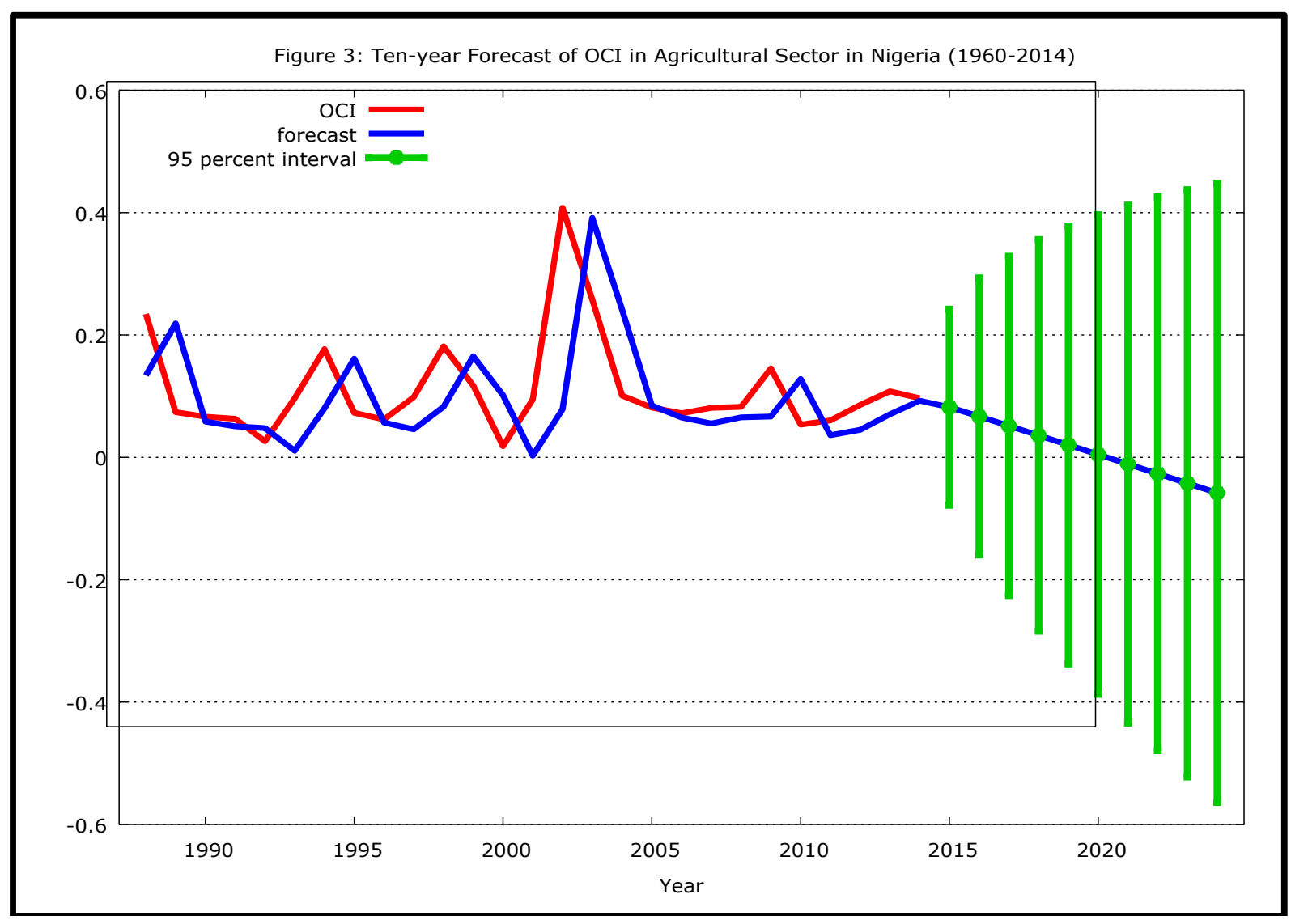

Figure 4: Ten - year Forecast of EDI in Agricultural Sector in Nigeria (1960 - 2014)

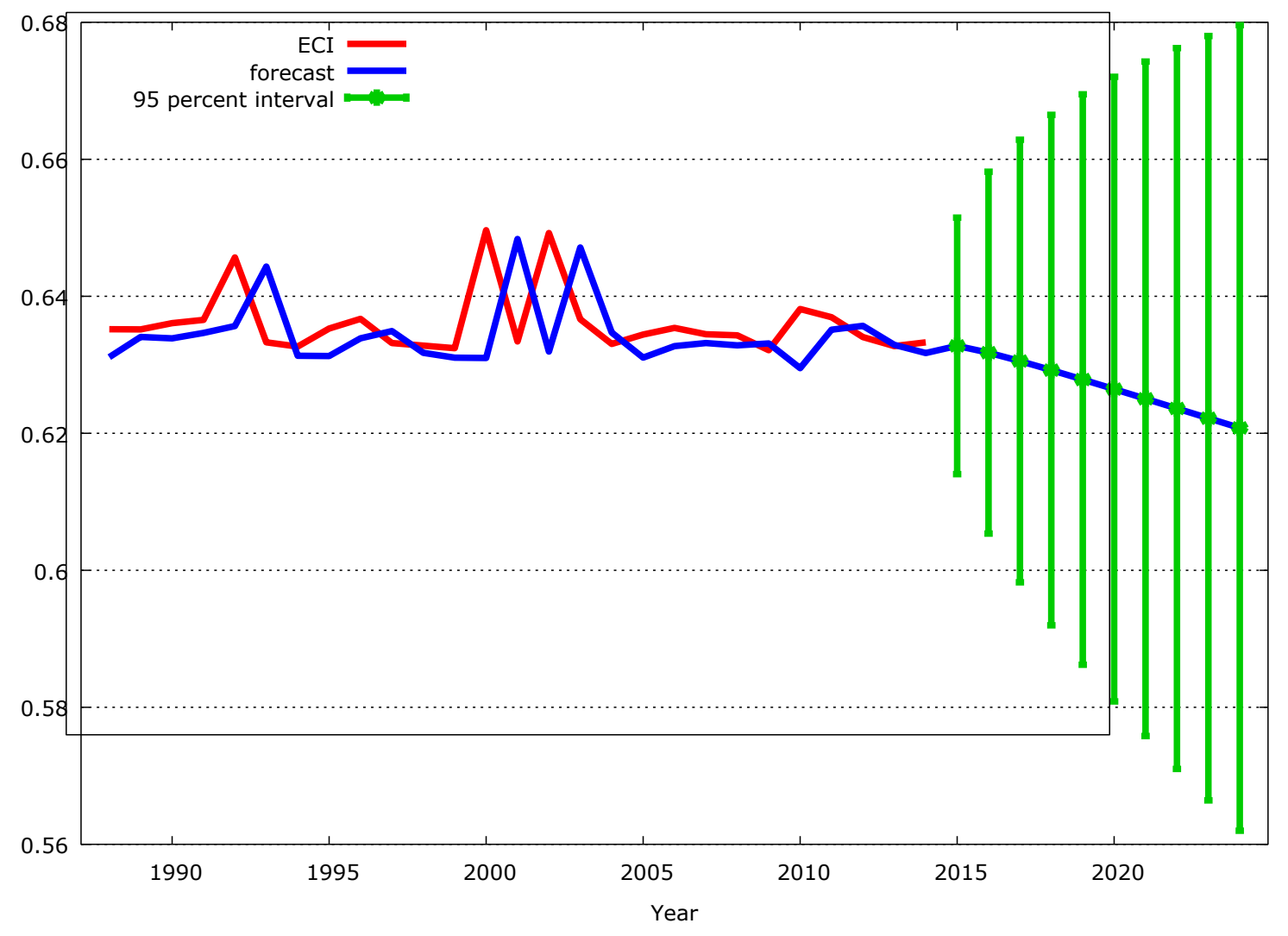


The predicted value of agricultural intensification indexes did not significantly differ from the actual values. The result revealed that, there is considerable stability in agricultural intensification in Nigeria.

Variance Decomposition and Impulse Analysis of Agricultural Intensification in Nigeria. Results in Table 8 and Table 9 show the relative contributions of the specified macroeconomic variables to the variation in agricultural intensification drive in Nigeria. Analysis revealed that, in the second period, the impact of crude oil price, energy consumption and foreign direct investment in agricultural sector as well as the external reserves were major exogenous factors that contributed to variations in Herfindhal agricultural diversification index. In the third and fourth periods, crude oil price, per capita income manufacturing output, industrial output, external reserves and Bank lending rates played significant roles in altering of $\mathrm{HCl}$. In the long-run, external reserve, industrial output, per capita income, crude oil price, Bank lending rate, foreign direct investment and non-oil imports were paramount in altering $\mathrm{HCl}$ of agricultural sector in Nigeria. A careful look at the result reveals that, shocks in the agricultural intensification index constitutes significant source of variation in itself both in the short and long-run. For instance, $\mathrm{HCl}$ witnessed about $93.72 \%$ shocked in period 2 and $46.27 \%$ in period 10 . However, in the long run it is noticed that the specified macroeconomic variables assumed increasing important in variation of $\mathrm{HCl}$. Shocks from external debt and inflation rate constituted the least sources of variations in $\mathrm{HCl}$ of agricultural sector in Nigeria.

Table 8 - Variance Decomposition of $\mathrm{HCl}$

\begin{tabular}{|c|c|c|c|c|c|c|c|c|c|c|c|c|c|c|}
\hline Period & S.E & $\mathrm{HCl}$ & COP & PCG & INF & FDI & UEM & IEC & IMP & LEN & CAS & EXD & EXR & $\mathrm{NOI}$ \\
\hline 1 & 0.035 & 100.000 & 0.000 & 0.000 & 0.000 & 0.000 & 0.000 & 0.000 & 0.000 & 0.000 & 0.000 & 0.000 & 0.000 & 0.000 \\
\hline 2 & 0.047 & 93.719 & 2.196 & 0.148 & 0.460 & 0.512 & 0.425 & 0.889 & 0.454 & 0.372 & 0.001 & 0.047 & 0.642 & 0.136 \\
\hline 3 & 0.055 & 76.906 & 4.419 & 2.603 & 0.648 & 1.322 & 0.389 & 1.026 & 7.580 & 2.194 & 0.086 & 0.229 & 2.404 & 0.192 \\
\hline 4 & 0.065 & 60.635 & 5.657 & 5.560 & 0.551 & 1.218 & 0.289 & 0.913 & 14.25 & 2.619 & 0.994 & 0.196 & 5.873 & 1.240 \\
\hline 5 & 0.069 & 57.313 & 5.031 & 5.095 & 0.975 & 1.297 & 0.359 & 2.009 & 15.46 & 3.053 & 0.880 & 0.175 & 6.748 & 1.601 \\
\hline 6 & 0.073 & 55.552 & 4.473 & 4.538 & 0.978 & 1.163 & 0.693 & 2.144 & 16.16 & 2.961 & 1.599 & 0.163 & 7.226 & 2.348 \\
\hline 7 & 0.078 & 52.431 & 3.966 & 7.259 & 0.876 & 1.069 & 0.710 & 1.928 & 16.70 & 3.243 & 1.498 & 0.153 & 7.799 & 2.360 \\
\hline 8 & 0.080 & 50.255 & 3.926 & 6.998 & 0.932 & 1.277 & 0.673 & 2.372 & 16.58 & 3.275 & 1.646 & 0.171 & 9.455 & 2.439 \\
\hline 9 & 0.081 & 48.692 & 3.801 & 6.783 & 1.027 & 2.504 & 0.707 & 2.353 & 16.29 & 3.216 & 2.001 & 0.168 & 10.04 & 2.417 \\
\hline 10 & 0.183 & 46.269 & 3.674 & 7.924 & 1.057 & 3.661 & 1.068 & 2.559 & 15.75 & 3.167 & 2.151 & 0.161 & 10.25 & 2.313 \\
\hline
\end{tabular}

Source: Authors estimation from gretl software.

Table 9 - Variance Decomposition of ECl

\begin{tabular}{|c|c|c|c|c|c|c|c|c|c|c|c|c|c|c|}
\hline Period & S.E & $\mathrm{ECl}$ & $\mathrm{COP}$ & PCG & INF & FDI & UEM & IEC & IMP & LEN & CAS & EXD & EXR & $\mathrm{NOI}$ \\
\hline 1 & 0.009 & 100.000 & 0.000 & 0.000 & 0.000 & 0.000 & 0.000 & 0.000 & 0.000 & 0.000 & 0.000 & 0.000 & 0.000 & 0.000 \\
\hline 2 & 0.012 & 80.965 & 1.089 & 3.633 & 1.725 & 0.239 & 0.006 & 2.999 & 1.415 & 0.753 & 4.962 & 0.007 & 1.556 & 0.651 \\
\hline 3 & 0.014 & 70.984 & 1.813 & 9.034 & 2.218 & 1.153 & 0.537 & 2.831 & 2.461 & 0.755 & 3.744 & 1.009 & 2.437 & 1.023 \\
\hline 4 & 0.014 & 68.472 & 1.778 & 8.938 & 2.090 & 1.092 & 0.776 & 2.778 & 3.040 & 0.712 & 5.563 & 1.094 & 2.671 & 0.994 \\
\hline 5 & 0.016 & 55.665 & 1.399 & 18.66 & 1.689 & 0.869 & 1.305 & 5.819 & 4.471 & 0.795 & 4.675 & 1.044 & 2.831 & 0.778 \\
\hline 6 & 0.017 & 50.341 & 1.703 & 19.97 & 1.699 & 0.884 & 1.531 & 5.297 & 6.464 & 0.859 & 4.762 & 1.547 & 4.241 & 0.707 \\
\hline 7 & 0.018 & 44.734 & 1.785 & 18.85 & 1.584 & 1.403 & 2.137 & 5.042 & 10.54 & 1.069 & 6.657 & 1.488 & 4.086 & 0.629 \\
\hline 8 & 0.019 & 40.247 & 3.315 & 18.94 & 1.453 & 2.720 & 2.503 & 6.707 & 11.28 & 0.965 & 6.135 & 1.357 & 3.804 & 0.571 \\
\hline 9 & 0.019 & 38.363 & 4.192 & 17.69 & 1.476 & 2.636 & 3.463 & 6.987 & 12.38 & 0.906 & 5.766 & 1.300 & 4.056 & 0.783 \\
\hline 10 & 0.021 & 36.058 & 4.744 & 20.01 & 1.354 & 2.398 & 3.532 & 6.963 & 12.49 & 0.849 & 5.372 & 1.409 & 3.739 & 1.078 \\
\hline
\end{tabular}

Source: Authors estimation from gretl software.

Result in table 9 also revealed that, per capita income, inflation, energy consumption, industrial output, credit to agricultural sector as well as the external reserves were important determinants of variations in $\mathrm{ECl}$ in the short run. In the long run, per capita income, crude oil price, industrial output, credit to agricultural sector and unemployment rate contributed to variations in $\mathrm{ECl}$. The examination of variations in agricultural intensification in the country in both short run and long run was further complemented by the impulse analysis conducted on the estimated indices of agricultural intensification. The impulse response of Agricultural intensification to changes in some macroeconomic variables is shown in figure 5 and figure 6. The innovation accounting test results revealed that the $\mathrm{HCl}$ and $\mathrm{ECl}$ fluctuate downward from period one to period ten. The effect of shocks in inflation in both indices showed an average negative impact in the short and long run periods. The impact of energy consumption revealed short run positive effect and long run negative impact in both indexes. 
It is observed that, the shock in the specified macroeconomic variables assumed unstable state in the short run, but converges to a near stable shock in the long run.
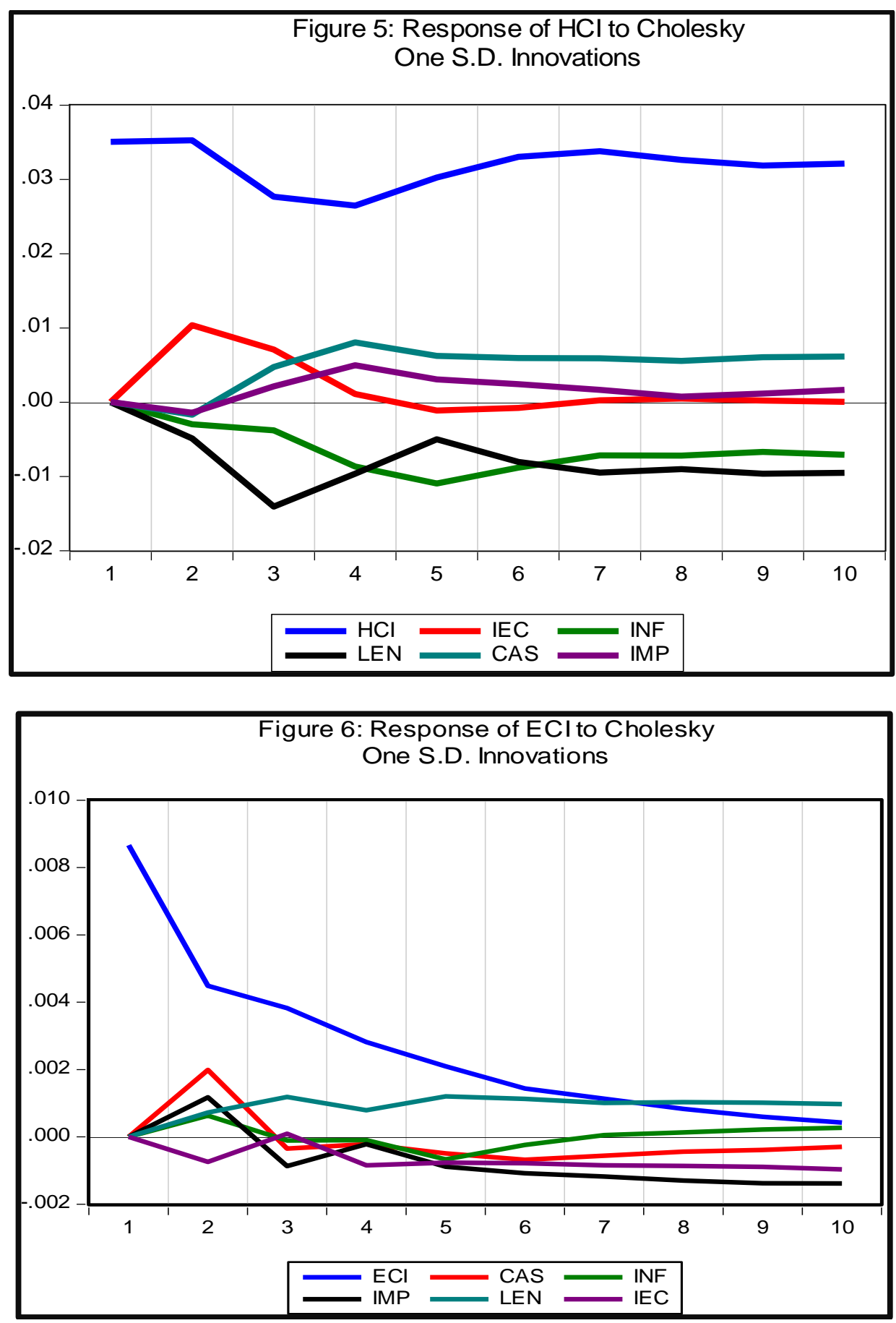

\section{SUMMARY AND RECOMMENDATIONS}

The study investigated the effect of macroeconomic variables fluctuation on agricultural intensification from 1960 to 2014 in Nigeria. Agricultural intensification was proxy by Herfindhal intensification index $(\mathrm{HCl})$, Ogive intensification index $(\mathrm{OCl})$ and Entropy Intensification index $(\mathrm{ECl})$. The relationships were tested with series of statistical and econometric methodologies. The orders of integration of series were ascertained using the Augmented Dickey-Fuller - GLS unit root test. The result indicated that the series used in the analysis were integrated of order one exception of OCl. Following this, Engle Granger two - 
step method and Johansen's test were conducted on the specified variables to test for the presence of cointegration among series. The result of both tests rejected the null hypothesis of no cointegration between agricultural intensification index and macroeconomic variables in Nigeria. The short run model for each of the index of agricultural intensification was generated for the co-integrated series. The error correction term was appropriately signed and statistically significant at conventional probability level for $\mathrm{HCl}$ and $\mathrm{ECl}$ indicating the possibility to converge to equilibrium in the long run, with intermediate adjustments captured by the differenced terms. These results implied that, the specified macroeconomic variables in the Nigeria's economy interacted in each period to re-establish the long-run equilibrium in agricultural intensification indices resulting from a short-run shocks or disturbances. The estimated indexes of agricultural intensification showed high degree of positive correlation and progressively declined assuming undulated trend from 1960 to 2014. The empirical result from the estimation of the long-run co-integration equation of agricultural intensification and macroeconomic variables identified the following as significant negative drivers of agricultural intensification in Nigeria; inflation, industrial output, external reserves, per capita income and electricity consumption: while crude oil price, external debt, Bank lending rate, foreign direct investment in agriculture and non-oil imports work in opposite direction. The short run model provided evidence of negative significant influence of inflation, external reserves and industrial output on agricultural intensification in Nigeria. Lending rate and crude oil price have positive effect. Also, a ten-year out sample forecast of agricultural intensification using $\mathrm{HCl}, \mathrm{OCl}$, and $\mathrm{ECl}$, foreseen a negative growth in these indices from 2015 to 2024. Variation in the intensification indices were further investigated by using impulse response function and variance decomposition analysis. The results were in agreement with the earlier reported results.

Based on the finding of this study, it is recommended that, the federal government of Nigeria should ensure the attainment of stability in the macroeconomic environment in order to achieved sustainable agricultural intensification in the country. Import policies should be given priority attention in order to protect domestic agricultural market and create incentives for the local farmers.

\section{REFERENCES}

1. Agu, C. (2007). "What does the Central Bank of Nigeria Target? An analysis of monetary policy reaction functions in Nigeria". Final report submitted to the African Economic Research Consortium, Nairobi, Kenya.

2. Akpan, S. B. and Patrick, I. V. (2015). Does Annual Output of Palm oil, Palm Kernel and Rubber correlate with some Macro-economic Policy variables in Nigeria? Nigerian Journal of Agriculture, Food and Environment. 11(1):66-72. ISSN: 0331 - 0787.

3. Akpan, S. B., and Edet. J. U. (2009). Relative Price Variability of Grains and Inflation rate movement in Nigeria. Global Journal of Agricultural Sciences vol. 8, N0.2, Pp 147-151. ISSN: 1596-2903.

4. Bernstein H., Crow, B. and Johnson, H. (eds), 1992, Rural Livelihoods: Crises and Responses, Oxford: Oxford University Press.

5. Binswanger, H.P. and Ruttan, V., 1978, Induced Innovation: Technology, Institutions and Development, Baltimore: Johns Hopkins University Press.

6. Brooks, C. (2008). Introductory econometrics for finance (2nd ed.). Cambridge, UK: Cambridge University Press.

7. Central Bank of Nigeria Statistical Bulletin 2004. A publication of the Central Bank of Nigeria.

8. Central Bank of Nigeria Website. Retrieved on the $10^{\text {th }}$ of March 2015. http://www.cenbank.org/.

9. Central Bank of Nigeria Statistical Bulletin 2005. A publication of the Central Bank of Nigeria.

10. Central Bank of Nigeria Website. Retrieved on the $8^{\text {th }}$ of March 2015. http://www.cenbank.org/. 
11. Chisasa, J. and Daniel Makina (2015). Bank Credit And Agricultural Output In South Africa: Cointegration, Short Run Dynamics And Causality. The Journal of Applied Business Research; Volume 31, Number 2; P 489-500. ISSN 0892-7626 (print); ISSN 2157-8834 (online).

12. Darma, N. A., and Bappah Tijjani (2014). Institutionalizing Development Planning in Nigeria: Context, Prospects and Policy Challenges. Journal of Economics and Sustainable Development; Vol.5, No.4, P 74 - 81. ISSN 2222-1700 (Paper) ISSN 22222855 (Online).

13. Diao, X, Wafer, M. and Vida, A. (2010). Strategic Issues on Growth in the Agricultural Sector and Reducing Poverty in Nigeria. International Food Policy Research Institute (IFPRIAbuja).

14. Elliott, G., T. J. Rothenberg and J. H. Stock, (1996). 'Efficient tests for an autoregressive unit root', Econometrica, Vol. 64. No. 4: Page, 813-836. DOI: 10.2307/2171846, ISSN: 1468-0262.

15. Eyo, E. O. (2008). Macroeconomic Environment and Agricultural Sector Growth in Nigeria. World Journal of Agricultural Sciences, 4(6), 781-786. ISSN : 1817-3047 (Online).e-ISSN: 1817-5082.

16. Fan S. B, Omilola B. Rhoe V., and Sheu A. S. (2008) Towards a Pro-Poor Agricultural Growth Strategy in Nigeria. International Food Policy Research Institute. Brief Paper No. 1, June 2008.

17. Gardner, Bruce. (1981). "On the Power of Macroeconomic Linkages to Explain Events in U.S. Agriculture." American Journal of Agricultural Economics 63: 871-78. Online ISSN: 1467-8276 - Print ISSN: 0002-9092.

18. Grossberg, A. J. (1982). Metropolitan industrial mix and cyclical employment stability. Regional Science perspectives, 12:13-35. ISSN: 0096 - 1197

19. Gujarati, D. (2003). Basic econometrics (4th ed.): New York, NY: McGraw Hill Company.

20. International Food Policy Research Institute Document on Agricultural Intensification 2013. http://www.ifpri.org/gfpr/2013/sustainable-agricultural-intensification. Retrieved on the $8^{\text {th }}$ of April, 2015.

21. Jackson, R.W. 1984. An evaluation of alternative measures of regional industrial diversification. Regional Studies, 18:103-112. ISSN: 0034-3404 (Print), 1360-0591 (Online)

22. Johansen, S., \& Juselius, K. (1990). Maximum likelihood estimation and inference on cointegration-with applications to the demand for money. Oxford bulletin of economics and statistics, 52(2), 169-210. DOI: 10.1111/j.1468-0084.1990.mp52002003.x. ISSN: 1468-0084.

23. Johansen, S. (1988). Statistical analysis of Cointegration Vectors. Journal of economic dynamics and control, 12(2/3), 231-254. ISSN: 0165-1889.

24. Kwon, D.-H., Koo, W. W. (2009). Interdependence of macro and agricultural economics: How sensitive is the relationship? American Journal of Agricultural Economics 91 (5), 1194-1200.

25. Lawal, T., and Abe O. (2011). National development in Nigeria: Issues, challenges and prospects. Journal of Public Administration and Policy Research Vol. 3(9), Pp. 237 -241. DOI: 10.5897/JPAPR11.012. ISSN $2141-2480$.

26. Msuya, E. (2007). The Impact of Foreign Direct Investment on Agricultural Productivity and Poverty Reduction in Tanzania. MPRA Paper No. 3671. Retrieved from: http://mpra.ub.uni-muenchen.de/3671/1/MPRA_paper_3671.pdf.

27. National Population Commission Website. Retrieved on the $8^{\text {th }}$ of March 2015. http://www.population.gov.ng/.

28. Nwosu, A. C. (1992). Structural Adjustment and Nigerian Agriculture. United State Department of Agricultural Economic Research Service. Agriculture and Trade Analysis Division.

29. Ogun, O. (1987). Nigeria's Trade Policy During and After the Oil Boom: An Appraisal, University of Ibadan, 1987. 
30. Olarinde, M. and Hussainatu A. (2014). Macroeconomic Policy and Agricultural Output in Nigeria: Implications for Food Security. American Journal of Economics 2014, 4(2): 99113. DOI: 10.5923/j.economics.20140402.02. E-ISSN: 2166-496X.

31. Omojimite, B. U. (2012). Institutions, Macroeconomic Policy and Growth of Agricultural Sector in Nigeria. Global Journal of Human Social Sciences. Vol. 12, Issues 1; Page 1 8. ISSN: 2249 460X (Online).

32. Rao D., Prasada, T., J. Coelli and Mohammad A. (2004). Agricultural productivity growth, employment and poverty in developing countries, 1970-2000. ILO, Employment Strategy Papers. From http://www.ilo.org/public/english/employment/strat/download/esp9.pdf.

33. Shiyani R.L. and H.R. Pandya (1998). Diversification of Agriculture in Gujarat: A Spatiotemporal Analysis. Indian Journal of Agricultural Economics, 53, (4): 627-639. ISSN: 0019-5014.

34. Smith, S.M., and C. S. Gibson, (1988). Industrial diversification in nonmetropolitan counties and its effect on economic stability. Western Journal of Agricultural Economics, 13:193-201. ISSN 1068-5502.

35. Sunday, B.; Ini-mfon, V.; Glory, E. and Daniel, E. (2012), "Agricultural Productivity and Macro-Economic Variable Fluctuation in Nigeria", International Journal of Economics and Finance; Vol. 4, No. 8; Pp.114-135. ISSN: 1916-971X E-ISSN: 1916-9728.

36. Tangermann, S. and Heidhues T. (1973). Inflation and Agriculture in EEC. European Review of Agricultural Economics. 37(4); 453 - 477. Doi: 10.1093/erae/1.2.127. ISSN: 1464 - 3618 (Online); ISSN: 0165 - 1587 (Print).

37. Taimini, L. D., Gervais, J. P., and Bruno L. (2010). Trade Liberalisation Effects on Agricultural Goods at different processing Stages. European Review of Agricultural Economics. 37(4); 453 - 477. Doi: 10.1093/erae/jbq035. ISSN: 1464 - 3618 (Online); ISSN: 0165 - 1587 (Print).

38. Udoh E., and Elias A. U. (2011). Ten Years of Industrial Policies under Democratic Governance in Nigeria: "New Wine in Old Bottle" European Journal of Social SciencesVolume 20, Number 2 248- 258. ISSN 1450 - 2267.

39. Udoh, E. J. and S. B. Akpan, (2007). Estimating Exportable Tree Crop Relative Price Variability and Inflation Movement under Different Policy Regimes in Nigeria. European Journal of Social Science: 5(2): 17-26. ISSN: $1450-2267$.

40. Ukoha, O. O. (2007). Relative Price Variability and Agricultural Policies in Nigeria. Agricultural Journal, 2: 258-264. ISSN: 1994 - 4616 (Online).

41. Ukoha, O. O. (1999). Macroeconomics Policy and the Effects on Agricultural Output in Nigeria' Federal university of Agriculture. College of Agricultural Economics, Rural Sociology and Extension, Nigeria.

42. World Bank (2007), World Development Report 2008: Agriculture for Development. Washington, World Bank.

43. World Bank (2014), "World Bank Development Indicators 2013", World Bank Washington D.C. 